\title{
Educational Intervention for the Prevention of Sexually Transmitted Infections in Seventh Grade Adolescents
}

\author{
Damarys Chacón 0'farrill ${ }^{1}$ and Alba Cortes Alfaro*2 \\ ${ }^{1}$ First Degree Specialist in Gynecology and Obstetrics, Cuba \\ ${ }^{2}$ Second Degree Specialist in School Hygiene, Cuba
}

*Corresponding author: Alba Cortes Alfaro, Second Degree Specialist in School Hygiene, Master in Epidemiology, Cuba

\begin{tabular}{|c|c|}
\hline ARTICLE INFO & ABSTRACT \\
\hline Received: 慧 June 08, 2019 & Introduction: adolescence is a vulnerable stage, exposed to risk factors such as: \\
\hline Published: 豐 June 14, 2019 & $\begin{array}{l}\text { early initiation of sexual relations and difficulties in the education of sexuality that con- } \\
\text { tribute to the increase of sexually transmitted infections (STIs) that includes HIV / AIDS. }\end{array}$ \\
\hline $\begin{array}{l}\text { tation: Damarys } \\
\text { rtes Alfaro. Educ }\end{array}$ & $\begin{array}{l}\text { Objective: to assess effects of educational intervention for the prevention of sexually } \\
\text { transmitted infections / acquired immunodeficiency virus in seventh grade adolescents, } \\
\text { during the school year 2017-2018. }\end{array}$ \\
\hline
\end{tabular}
for the Prevention of Sexually Transmitted Infections in Seventh Grade Adolescents. Biomed J Sci \& Tech Res 18(5)2019. BJSTR. MS.ID.003214.

Keywords: DeCS; Adolescence; STIs / HIV / AIDS; Prevention

Method: study of educational intervention quasi-experimental pre and post test with group control. Location: Basic High School "Antonio José Oviedo". Municipality San José de las Lajas, Mayabeque. The questionnaire of the Department of School Health of the National Institute of Hygiene, Epidemiology and Microbiology was used to collect the information. Universe: 150 students and sample of 60 students selected by the simple random method. It was intervened in 15 sessions. For the evaluation of the results, the descriptive and inferential statistics (J squared) were applied.

Results: predominance of the female sex (55\%), 38\% had sexual relations. The level of knowledge, perception of risk, beliefs and attitudes amount to 90, 93, 73 and 86\% respectively post intervention. Significantly increased the perception of risk that despite knowing the person with whom he would have sexual relations, this could be a carrier of HIV $(100 \%), 96 \%$ responded that they could have been exposed to an HIV infection in his first sexual relationship.

Conclusion: The methodology used to prevent STI-HIV / AIDS was useful and effective.

\section{Introduction}

Adolescence is a stage in which social interests appear and feelings never before experienced blossom, which together with physiological changes make evident a significant transformation in this subject that little by little ceases to be a child [1]. It is an era of continuous biopsychosocial changes, where the aim is to strengthen the personality and the roles that will develop in society. It is considered a period of human development in which an important decision-making process of the subject begins with respect to itself; it is also the beginning of the transition towards adulthood. The adolescent often faces, without possessing the necessary psychological resources to the problem of starting to outline the ways to follow to fully incorporate into society, so that his projection of life and his position within it change [2].

This is also a formative stage, crucial in the life cycle; identity, autonomy and the project of life are being conformed, reason why an integral approach of the sexuality is necessary, taking into account that the influence exerted of the different spaces where the adolescents develop in their daily life is determinant, if considers that at this stage of life, relationships with their peers are very significant $[3,4]$. With regard to the relationship of couple begins to relegate friendship relations to the background. Relationships at this stage tend to be unstable, since they have an experimental 
nature and contribute to the development of the self-assessment or personal identity and, in particular, the sexual and gender identity of the adolescent [5-7].

One of the fundamental aspects in these ages is sex, indissolubly linked to the human being as a biological entity; it is a natural instinctive process, modified by social patterns. This stage should be one of full enjoyment and for this purpose, adequate orientation is necessary [8]. Adolescents do not count (in many cases) with an adequate sex education, so they constitute a risk group par excellence for contracting sexually transmitted diseases and they can also reach early motherhood or fatherhood for which they are neither objective nor Subjectively prepared [7]. In the choice of the couple the adolescents have difficulties to make coincide their ideal -from the physical point of view- with the ideal to which they aspire according to their psychological and moral qualities, due to the great importance that they give to the corporal image. In adolescence, the stereotypes corresponding to the male and female sex roles are polarized in a particularly abrupt manner, and the need to correspond with them becomes more acute than ever $[5,6]$.

In men - more than in females - sexual maturity anticipates the development of the resources necessary to establish a relationship in which stability, psychological intimacy and mutual understanding are achieved [7].

The females, also attending to the stereotypes linked to their gender role, are more free to give themselves from the affective in the couple's relationship and, at the same time, taking into account what is expected in their sexual role, they must hide their feelings, since "wait" and "take their place" are qualities that are linked to values such as feminine dignity and reputation. This separation between what is erotic-sensual and tender depends, to a large extent, on macho prejudices, according to which the traditional style of masculinity and virility are legitimized by the approach of man to woman from positions of strength $[6,7]$. Therefore, the health of adolescents could be at risk due to inappropriate sexual and social behavior. The combination of both is frequent and very dangerous for sexual and reproductive health [9]. The main consequence of sexual risk behavior is framed in the reproductive damage with presence in the increase of Sexually Transmitted Infections [3]. Statistics worldwide estimate that in 20151.2 million adolescents died, that is, more than 3000 a day, mostly due to preventable or treatable causes [10].

New HIV infections among children have decreased by $58 \%$ since 2001 however it is reported that in 2013, 240,000 children were infected by the virus. AIDS is today the leading cause of death among adolescents (10 to 19 years old) in Africa and the second most common among adolescents worldwide. One million pregnant women get infected every year with syphilis. In 2012, Syphilis affected 360,000 pregnancies [11]. In Cuba, the average age of onset of sexual intercourse is increasingly low; The earlier the first intercourse occurs, the greater are the risks of pregnancy and of con- tracting sexually transmitted diseases [12]. This demands greater actions aimed at protecting adolescents in terms of sexuality, since it is a universal right of all people in relation to the full, healthy and free enjoyment of all discrimination and social injustice.

\section{Methods}

\section{Type of Research}

study of educational intervention quasi-experimental pre-post test with quantum-quantitative control group in adolescents of the Basic Secondary School "Antonio José Oviedo" of the municipality of San José de las Lajas, during the school year from doctors previously trained for the study in question. Methodologies were applied for the prevention of STIs-HIV / AIDS in adolescents and young people in the school setting [12-15]. The study universe consisted of 1507 th grade students. Shows 60 students selected by the simple random method. It was conditioned by the requirements of the activity according to the number of participants, the goals and pedagogical methods to be used.

\section{Inclusion Criteria}

a) $7^{\text {th }}$ grade students with ages between 12 and 13 years old, belonging to the Basic Secondary School "Antonio José Oviedo"

b) Approval of parents and students to participate in the study.

\section{Exclusion Criteria}

a) Students who were absent from 3 sessions.

5. Techniques and Procedures

\section{The Investigation was Divided into Three Stages}

Diagnostic Stage: The introduction to the educational program was made, where the work was made known. The survey was applied to the students in order to specify the degree of information they have about STIs, prior to the educational intervention. The survey model was the informative support of the work; It allowed to collect all the variables of interest, such as: sociodemographic, of sexual activity, knowledge of STIs-HIV / AIDS, complications, beliefs about these, knowledge about the condom, perception of risk and attitude toward people infected by STIs. He was asked for his written approval to be included in it.

Intervention Stage: The results of the initial questionnaire were analyzed, and the educational strategy was designed. There were 15 work sessions in the form of workshops with a weekly frequency and a duration of 45 minutes, for 6 months. During the sessions, knowledge of the most frequent STIs, predominant manifestations, transmission routes, complications related to them was deepened, correct condom use was emphasized, values such as companionship, altruism were strengthened, myths and erroneous beliefs were demolished. STI-HIV / AIDS and condoms, the fields of vision were expanded close to the perception of risk and sexual risk behaviors for the acquisition of STIs in general. Participatory 
techniques were used with the aim of achieving the participation, animation and integration of the participants and making the understanding of these issues easier, as well as favoring reflection.

Evaluation Stage: It was done six weeks later, where the initial survey was applied again. In this way, the evaluation that was carried out before and after the intervention stage made it possible to assess the changes produced in the knowledge, which were considered as the effect or result of the educational tasks carried out with the adolescents. The results are presented in the form of tables for better understanding.

\section{Operationalization of the Variables}

\section{Ethical Aspects}

communication to the scientific council of the institution. No disclosure and confidentiality of the student's name. The data will only be used for scientific purposes.

\section{Processing of Information}

The information was obtained from the results of the questionnaire created by the INHE-M [14]. The processing was done in the Microsoft Excel Office 2007 database, the data was collected in an emptying sheet using the Excel program of the Office, which allowed expressing the information by means of the descriptive percentage statistics and for the inferential statistics the Chi square was used through the epidemiological analysis of tabulated data (EPIDAT version 3.1) (Table 1). The results were subjected to analysis and discussion, comparing them with the results described in the literature by other authors, based on an inductive and deductive analysis, reaching conclusions and making recommendations aimed at establishing a group of actions aimed at increasing knowledge about about STIs-HIV / AIDS in the study group. The qualitative component was related to the social aspects that aimed to understand certain behaviors, attitudes and how the adolescents have been affected by events that happened around them (Table 2). The subjective reality that allowed the interpretive richness and contextualized the phenomenon by expanding the investigation was analyzed [16]. The quantitative study was carried out by quasi-experimental study before and after where the data were collected through an instrument created for this purpose, measuring the phenomenon with the use of statistical methods, this allowed objectively to analyze reality [16].

Table 1: Excel program of the Office, which allowed expressing the information by means of the descriptive percentage statistics and for the inferential statistics the Chi square was used through the epidemiological analysis of tabulated data (EPIDAT version 3.1).

\begin{tabular}{|c|c|c|c|c|}
\hline Knowledge Variable & Type of variable & Scale & Description & Indicator \\
\hline Sex & $\begin{array}{l}\text { Qualitative nominal } \\
\text { dichotomous }\end{array}$ & $\begin{array}{l}\text { Male } \\
\text { Female }\end{array}$ & Female & $\begin{array}{l}\text { Absolute frequency } \\
\text { and percentage }\end{array}$ \\
\hline Civil status & $\begin{array}{l}\text { Qualitative nominal } \\
\text { polytomy }\end{array}$ & $\begin{array}{c}\text { Single } \\
\text { Married } \\
\text { Consensual union }\end{array}$ & $\begin{array}{l}\text { According to relationship of } \\
\text { couple }\end{array}$ & $\begin{array}{l}\text { Absolute frequency } \\
\text { and percentage }\end{array}$ \\
\hline Sexual relations & $\begin{array}{l}\text { Qualitative nominal } \\
\text { dichotomous }\end{array}$ & $\begin{array}{l}\text { Yes } \\
\text { No } \\
\end{array}$ & $\begin{array}{l}\text { Sexual contact between people } \\
\text { existing or not coitus. }\end{array}$ & $\begin{array}{l}\text { Absolute frequency } \\
\text { and percentage }\end{array}$ \\
\hline $\begin{array}{l}\text { Identification of STIs of } \\
\text { greater frequency. }\end{array}$ & $\begin{array}{l}\text { Qualitative nominal } \\
\text { dichotomous }\end{array}$ & $\begin{array}{l}\text { Adequate: From } 9 \text { correct answers } \\
\qquad \geq 75 \% \\
\text { Inadequate: (less than established) } \\
\quad \text { Total minimum points: } 18\end{array}$ & $\begin{array}{l}\text { According to the knowledge about } \\
\text { the etiology of STIs. }\end{array}$ & $\begin{array}{l}\text { Absolute frequency } \\
\text { and percentage }\end{array}$ \\
\hline $\begin{array}{l}\text { Knowledge of curable } \\
\text { STIs. }\end{array}$ & $\begin{array}{l}\text { Qualitative nominal } \\
\text { dichotomous }\end{array}$ & $\begin{array}{c}\text { Adequate: } \\
\text { It cures: } \geq 3 \text { responses } \\
\text { Correct } \\
(75 \%) \\
\text { It does not cure: } \geq 2 \text { correct } \\
\text { answers } \\
(66 \%) \\
\text { Inadequate: lower than established. } \\
\text { Total minimum points: } \\
6 \text { points is cured } 4 \text { points does not } \\
\text { heal }\end{array}$ & $\begin{array}{l}\text { About the knowledge they have } \\
\text { regarding available therapy } \\
\text { currently for the eradication of the } \\
\text { causal agent. }\end{array}$ & $\begin{array}{l}\text { Absolute frequency } \\
\text { and percentage }\end{array}$ \\
\hline $\begin{array}{l}\text { Knowledge about the } \\
\text { prevention of STIs. }\end{array}$ & $\begin{array}{l}\text { Qualitative nominal } \\
\text { dichotomous }\end{array}$ & $\begin{array}{c}\text { } \geq 2 \text { suitable } \\
\text { Correct answers (66\%) } \\
\text { Inadequate: lower than established. } \\
\text { Total minimum points: } 4\end{array}$ & $\begin{array}{l}\text { Knowledge of measures aimed at } \\
\text { preventing the initial appearance } \\
\text { of an STI- HIV / AIDS. }\end{array}$ & $\begin{array}{l}\text { Absolute frequency } \\
\text { and percentage }\end{array}$ \\
\hline
\end{tabular}




\begin{tabular}{|c|c|c|c|c|}
\hline $\begin{array}{l}\text { Knowledge of risky } \\
\text { behaviors }\end{array}$ & $\begin{array}{l}\text { Qualitative nominal } \\
\text { dichotomous }\end{array}$ & $\begin{array}{l}\geq 9 \text { adequate With correct answers } \\
(69 \%) \text { Inadequate: lower than } \\
\text { established. Total minimum points: } \\
18\end{array}$ & $\begin{array}{l}\text { Specific form of behavior of } \\
\text { which its relation to an increased } \\
\text { susceptibility is known. For } \\
\text { a specific disease based on } \\
\text { epidemiological and social data. }\end{array}$ & \\
\hline $\begin{array}{c}\text { Knowledge of the routes } \\
\text { of transmission of STIs- } \\
\text { HIV / AIDS }\end{array}$ & $\begin{array}{l}\text { Qualitative nominal } \\
\text { dichotomous }\end{array}$ & $\begin{array}{l}\qquad \geq 6 \text { adequate } \\
\text { With correct answers }(66 \%) \\
\text { Inadequate: lower than established. } \\
\text { Total minimum points: } 12\end{array}$ & $\begin{array}{c}\text { According to your knowledge } \\
\text { of the different ways in which a } \\
\text { person can acquire STIs- HIV / } \\
\text { AIDS. }\end{array}$ & $\begin{array}{l}\text { Absolute frequency } \\
\text { and percentage }\end{array}$ \\
\hline $\begin{array}{l}\text { Knowledge about clinical } \\
\text { manifestations that may } \\
\text { indicate the existence of } \\
\text { STI- HIV / AIDS. }\end{array}$ & $\begin{array}{l}\text { Qualitative nominal } \\
\text { dichotomous }\end{array}$ & $\begin{array}{c}\qquad 11 \\
\text { adequate } \\
\text { Correct answers } 73 \% \\
\text { Inadequate: lower than established. } \\
\text { Total minimum points: } 22\end{array}$ & $\begin{array}{l}\text { According to the knowledge of the } \\
\text { main symptoms or signs that show } \\
\text { the existence of } \\
\text { STIs- HIV / AIDS. }\end{array}$ & $\begin{array}{l}\text { Absolute frequency } \\
\text { and percentage }\end{array}$ \\
\hline $\begin{array}{l}\text { Knowledge about } \\
\text { the consequences of } \\
\text { contracting STIs-HIV / } \\
\text { AIDS. }\end{array}$ & $\begin{array}{l}\text { Qualitative nominal } \\
\text { dichotomous }\end{array}$ & $\begin{array}{c}\qquad 10 \\
\text { adequate } \\
\text { Correct answers: } 76 \% \\
\text { Inadequate: lower than established. } \\
\text { Total minimum points: } 20\end{array}$ & $\begin{array}{l}\text { It refers to the event or diseases } \\
\text { resulting from STI-HIV / AIDS }\end{array}$ & $\begin{array}{l}\text { Absolute frequency } \\
\text { and percentage }\end{array}$ \\
\hline $\begin{array}{l}\text { Knowledge about the use } \\
\text { of condoms. }\end{array}$ & $\begin{array}{l}\text { Qualitative nominal } \\
\text { dichotomous }\end{array}$ & $\begin{array}{c}\geq 3 \\
\text { adequate } \\
\text { Correct answers: } 33 \% \\
\text { Inadequate: lower than established: } \\
44 \% \\
\text { Total minimum points: } 12\end{array}$ & $\begin{array}{l}\text { According to the knowledge about } \\
\text { the use of the condom in relation } \\
\text { to sexual practice. }\end{array}$ & $\begin{array}{l}\text { Absolute frequency } \\
\text { and percentage }\end{array}$ \\
\hline $\begin{array}{l}\text { Knowledge about the } \\
\text { transmissibility of HIV }\end{array}$ & $\begin{array}{l}\text { Qualitative nominal } \\
\text { dichotomous }\end{array}$ & $\begin{array}{l}\text { Yes: Adequate }(100 \%) \\
\text { Inadequate: } \\
\text { Do not }\end{array}$ & $\begin{array}{l}\text { In relation to the transmissibility } \\
\text { according to the stages in which } \\
\text { the person living with the virus } \\
\text { (PVVIH) transits }\end{array}$ & $\begin{array}{l}\text { Absolute frequency } \\
\text { and percentage }\end{array}$ \\
\hline $\begin{array}{l}\text { Knowledge of the } \\
\text { moment of condom use }\end{array}$ & $\begin{array}{l}\text { Qualitative nominal } \\
\text { dichotomous }\end{array}$ & Qualitative nominal dichotomous & $\begin{array}{l}\text { Related to the correct form } \\
\text { regarding the time of placement of } \\
\text { the condom. }\end{array}$ & $\begin{array}{l}\text { Absolute frequency } \\
\text { and percentage }\end{array}$ \\
\hline $\begin{array}{l}\text { Knowledge of the } \\
\text { moment of condom use }\end{array}$ & $\begin{array}{l}\text { Qualitative nominal } \\
\text { dichotomous }\end{array}$ & $\begin{array}{l}\text { No: Adequate }(100 \%) \\
\text { Inadequate: } \\
\text { Yes }\end{array}$ & Related to the myth of its use & $\begin{array}{l}\text { Absolute frequency } \\
\text { and percentage }\end{array}$ \\
\hline
\end{tabular}

Table 2: The adolescents have been affected by events that happened around them.

\begin{tabular}{|c|c|c|c|c|}
\hline $\begin{array}{l}\text { Variables of perception of risk, } \\
\text { attitudes, and beliefs }\end{array}$ & Type of variable & Scale & Description & Indicator \\
\hline $\begin{array}{l}\text { Perception of the risk of } \\
\text { contracting STI-HIV / AIDS }\end{array}$ & $\begin{array}{l}\text { Qualitative } \\
\text { nominal } \\
\text { dichotomous }\end{array}$ & $\begin{array}{l}\text { Adequate: Yes: Score: } 3 \text { points } \\
\text { Total correct score: } 24 \\
\text { Inadequate No: } 1 \text { point. }\end{array}$ & $\begin{array}{l}\text { Vulnerability perceived by the person to } \\
\text { be considered at risk or not of getting sick } \\
\text { with STI-HIV / AIDS }\end{array}$ & $\begin{array}{l}\text { Absolute } \\
\text { frequency and } \\
\text { percentage }\end{array}$ \\
\hline Attitude towards STIs & $\begin{array}{l}\text { Qualitative } \\
\text { nominal } \\
\text { dichotomous }\end{array}$ & $\begin{array}{l}\text { Vulnerability perceived by the } \\
\text { person to be considered at risk } \\
\text { or not of getting sick with STI- } \\
\text { HIV / AIDS }\end{array}$ & $\begin{array}{l}\text { The ability of the person to transform } \\
\text { their sexual behavior and attitude towards } \\
\text { people with STI-HIV / AIDS depending on } \\
\text { knowledge }\end{array}$ & $\begin{array}{l}\text { Absolute } \\
\text { frequency and } \\
\text { percentage }\end{array}$ \\
\hline Beliefs about STIs & $\begin{array}{l}\text { Qualitative } \\
\text { nominal } \\
\text { dichotomous }\end{array}$ & $\begin{array}{l}\text { Adequate: Yes: Score: } 3 \text { points } \\
\text { Total correct score: } 6 \\
\text { Inappropriate No and I do not } \\
\text { know: } 1 \text { point }\end{array}$ & $\begin{array}{l}\text { Positive changes in relation to people with } \\
\text { STIs-HIV / AIDS }\end{array}$ & $\begin{array}{l}\text { Absolute } \\
\text { frequency and } \\
\text { percentage }\end{array}$ \\
\hline
\end{tabular}




\section{Results}

It is observed that 33 students belonged to the female sex and that the highest percentage belongs to single marital status calling attention to the fact that 4 students declared having stable relationships with consensual or married union. It was observed that 23 students had had sexual relations for $38 \%$ of the total and of them the females present the highest percentage (44\%), which was statistically significant ( $p=0,2272$ ). The results of the responses considered adequate before and after the educational intervention on STI / HIV-AIDS are shown. It is observed that there is an increase in the variables of knowledge, perception of risk and attitude, reaching 93, 90, 73\% post intervention respectively, beliefs rose from 26 to $86 \%$, it was statistically significant.

In the case of the results obtained in the control group on the level of knowledge, risk perception, attitudes and beliefs, it is ob-

Table 3: Sociodemographic distribution of the students of the experimental group and the control group.

\begin{tabular}{|c|c|c|c|c|c|c|}
\hline \multicolumn{7}{|c|}{ Sociodemographic variables } \\
\hline & \multicolumn{2}{|c|}{ Grupo control } & \multicolumn{2}{|c|}{ Grupo experimental } & \multicolumn{2}{|c|}{ Total } \\
\hline \multicolumn{7}{|c|}{ Sex } \\
\hline & No & $\%$ & No & $\%$ & No & $\%$ \\
\hline Male & 14 & 47 & 13 & 43 & 27 & 45 \\
\hline Female & 16 & 53 & 17 & 57 & 33 & 55 \\
\hline Total & 30 & 100 & 30 & 100 & 60 & 100 \\
\hline \multicolumn{7}{|c|}{ Civil status } \\
\hline Single & 29 & 97 & 27 & 90 & 56 & 93 \\
\hline Married & - & - & 1 & 3 & 1 & 2 \\
\hline Consensual union & 1 & 3 & 2 & 7 & 3 & 5 \\
\hline Total & 30 & 100 & 30 & 100 & 60 & 100 \\
\hline
\end{tabular}

Note: Basic Secondary Antonio José Oviedo

Table 4: Distribution of adolescents according to sex and sexual relations. Experimental group and control. Basic Secondary Antonio José Oviedo.

\begin{tabular}{|c|c|c|c|c|c|c|c|c|c|}
\hline \multicolumn{10}{|c|}{ Sexual relations } \\
\hline & \multicolumn{3}{|c|}{ Control group } & \multicolumn{3}{|c|}{ Group Experimental } & \multirow{2}{*}{\multicolumn{3}{|c|}{$\begin{array}{c}\text { Total adolescents of both groups according to sex / } \\
\text { Teenagers } \\
\text { with sex }\end{array}$}} \\
\hline \multirow[t]{2}{*}{ Sex } & \multirow[t]{2}{*}{$\begin{array}{c}\text { Total } \\
\text { students }\end{array}$} & \multicolumn{2}{|c|}{ Active sexual life } & \multirow{2}{*}{$\begin{array}{c}\text { Total } \\
\text { students }\end{array}$} & \multicolumn{2}{|c|}{ Active sexual life } & & & \\
\hline & & No & $\%$ & & No & $\%$ & Total & No & $\%$ \\
\hline Female & 16 & 7 & 44 & 17 & 9 & 53 & 33 & 16 & 48 \\
\hline Male & 14 & 3 & 21 & 13 & 4 & 31 & 27 & 7 & 26 \\
\hline Total & 30 & 10 & 33 & 30 & 13 & 43 & 60 & 23 & 38 \\
\hline
\end{tabular}

Note: $p=0,2272$

Table 5: Behavior of variables under study in the experimental group.

\begin{tabular}{|c|c|c|c|c|}
\hline \multirow{2}{*}{ Variables in study } & \multicolumn{2}{|c|}{ Before the intervention } & \multicolumn{2}{c|}{ After the intervention } \\
\cline { 2 - 5 } & Appropriate answers & Appropriate answers & \% \\
\hline Level of knowledge & 6 & 20 & 28 & 93 \\
\hline Perception of risk & 7 & 23 & 27 & 73 \\
\hline Attitude & 9 & 30 & 26 & 86 \\
\hline Beliefs & 8 & 26 & 26 \\
\hline
\end{tabular}


Note: $p=0.000$

Table 6: Behavior of the variables under study in the control group.

\begin{tabular}{|c|c|c|c|c|}
\hline \multirow{2}{*}{ Variables in study } & \multicolumn{2}{|c|}{ Before the intervention } & \multicolumn{2}{c|}{ After the intervention } \\
\cline { 2 - 5 } & Appropriate answers & \% & Appropriate answers & 18,42 \\
\hline Level of knowledge & 9 & 22,50 & 5 & 13,16 \\
\hline Perception of risk & 7 & 17,50 & 10 & 26,32 \\
\hline Attitude & 10 & 25 & 6 & 15,79 \\
\hline Beliefs & 5 & 20 & & 79 \\
\hline
\end{tabular}

Note: $(\mathrm{p}=0.000)$

Table 7: Relationship between the perception of risk of contracting HIV / AIDS with well-known people and the question of whether it will be a carrier of the virus. Experimental group.

\begin{tabular}{|c|c|c|c|c|}
\hline Educative intervention & \multicolumn{2}{|c|}{ Risk of contracting HIV / AIDS with well-known people } & \multicolumn{2}{|c|}{$\begin{array}{c}\text { I wonder if he will have HIV / AIDS before starting a } \\
\text { sexual relationship }\end{array}$} \\
\hline $\begin{array}{c}\text { Answers } \\
\text { Adequate }\end{array}$ & No & $\%$ & No & $\%$ \\
\hline Before & 3 & 10 & 9 & 30 \\
\hline After & 26 & 86 & 30 & 100 \\
\hline
\end{tabular}

Note: $\mathrm{p}=0,1732$

Table 8: Relationship between perception questions: being exposed to AIDS in the first sexual relationship and the possibility that the couple may be infected or sick. Experimental group.

\begin{tabular}{|c|c|c|c|c|}
\hline Educative intervention & \multicolumn{2}{|c|}{ Being exposed to AIDS in the first sexual relationship. } & \multicolumn{2}{|c|}{$\begin{array}{c}\text { I wonder if he will have HIV / AIDS before starting a } \\
\text { relationship sexual ón }\end{array}$} \\
\hline $\begin{array}{c}\text { Answers } \\
\text { Adequate }\end{array}$ & No & $\%$ & No & $\%$ \\
\hline Before & 3 & 10 & 7 & 23 \\
\hline After & 25 & 83 & 29 & 96 \\
\hline
\end{tabular}

Note: $\mathrm{P}=0,3400$

\section{Discussion}

After showing the results, the predominance of the female sex was appreciated, not coinciding with studies of the socio-demographic characteristics of the adolescent population in Cuba where male adolescents (689 867, 51.50\%) over female (649 468) predominate very discreetly. 48.49\%) [12]. It is also evident that although most of them were single, we can not forget that 4 students were with a stable union, either married or consensual free union, and that 23 students declared having presented sexual relations at some point, corresponding also with greater percent to the female sex. It coincides with other studies on this topic. According to the results of the 2014 MICS, $15.8 \%$ of women between 15 and 19 years of age, were married or in union (16\%), 31.2\% of those under 18 had been married in marriage at least once and $5.9 \%$ before the age of $15.12 .9 \%$ of women under fifteen years old reported having had sexual relations [17]. STIs have increased their incidence of gonorrhea, syphilis and condylomas among Cuban adolescents and youngsters. This is a worrisome situation. After observing the results, before the educational intervention, the students had a low level of knowledge about STIs / HIV-AIDS. Most of them initially did not know how to identify the different types of existing infections, whether they are curable or not, the routes of transmission, clinical manifestations and possible complications. With respect to the use of condoms, they did not identify well when it was the sexual act to place it or if it was safer to use two at the same time. These inadequate knowledge then lead to the appearance of STIs at an early age [17-19].

The authors consider that the low perception of risk presented by adolescents is clear, considering that knowing "well" a person, or being their first sexual relationship is not exposed to AIDS or other STIs, which is a great mistake, As it is well known, "AIDS does not have a face", a phrase that is frequently repeated in the audiovisual and folding promotion media. This situation is due to the fact that adolescents are not biopsychosocially prepared to initiate sexual relations, in this case evidenced by the seventh grade students of the research who are still in an early adolescence and this affirmation is in agreement with other authors [20-25]. In the case of attitudes and beliefs initially they were also reflected in an inadequate way. Attitudes although after the intervention showed better results we ratify that they are more complex in their process since they need interventions of greater durability in time to take their modifications as true and significant. Since the fact that a person acquires a certain level of knowledge does not mean that they change their attitude towards dealing with HIV-positive 
persons, although in Cuban society solidarity and humanism prevail as general distinctive characters [26].

Although before the intervention we found that the variables were unsatisfactory, we now propose that the expected results were obtained, coinciding with other educational interventions already carried out, where up to $79 \%$ and $85 \%$ of satisfactory results were achieved [26-25]. When comparing the data obtained with the empirical investigations carried out after the intervention, it can be seen that the results are in tune with the current trends in the effectiveness of the interventions, with the one proposed by this research being one of the most satisfactory and significant results [26-31]. The economic valuation and the social contribution are evident in that these results affect not only the individual welfare but social, with the decrease of these infections from an early age, the risk of infection is reduced and with it the excessive use of medicines that cost so much result for the Cuban economy [32].

\section{Conclusion}

a) There was a low level of knowledge about STIs / HIV-AIDS in seventh grade adolescents despite receiving such topics as part of their curricular educational pre-intervention program. The application of the questionnaire collected information on different variables that allowed the analysis of the adolescent as being biopsychosocial.

b) There was an increase in adolescents' knowledge about STI / HIV-AIDS post-intervention as well as the perception of risk, attitudes and beliefs.

c) The implementation of educational methodology in adolescents was effective in raising the level of knowledge, risk perception, attitudes and beliefs about STIs / HIV-AIDS.

\section{References}

1. Cruz Sánchez F, Rodríguez Alonso B, Alonso Uría RU (2014) Childcare in adolescence. Havana: Ministry of Public Health 15: 16.

2. Guerrero Borrego N, Pérez Enríquez M (2016) Integral education of sexuality in childhood, adolescence and youth. Conceptual approach In Guerrero Borrego N. Reflections and views on sexuality in childhood, adolescence and youth. Havana: CENESEX 21.

3. Calero Yera E, Rodriguez Roura S, Trumbull Jorlen A (2017) Approach to sexuality in adolescence. Rev Hum Med 17(3): 577-592.

4. Hernández Machín LE, Martínez Malo Gutiérrez NH, Cruz Hernández Y (2014) Evaluation of the level of knowledge of young adolescents about sexuality. Rev Medical Sciences 18(1): 33-44.

5. Domínguez García L, Ibarra Mustelier L (2003) Youth and life projects. In Selection of readings Psychology of Development: Adolescence and Youth. Havana: Editorial Félix Varela 524.

6. Domínguez García L (2007) Development Psychology: Problems, Principles and Categories. Havana: Editorial Félix Varela.

7. Domínguez García L (2015) Social situation of the development of a group of young alcoholics. Rev Cub of Military Medicine 44(3): 301-313.

8. Rey Rodríguez GA, Cancio Bello Ayes Cl, Domínguez García L (2016) Are we the same? Characterization of racial identity in a group of adolescents in Havana. Journal of the Cuban Institute of Cultural Research Juan Marinello 3.
9. Mota J (2017) Carriers of the fire. Rev Adoleca 13-18.

10. (2001) Joint United Nations Program on HIV / AIDS. General Assembly of the United Nations on HIV / AIDS. Summary of the Declaration of commitment in the fight against HIV / AIDS, New York: Unaids, USA, p. 25-27.

11. (2016) World Health Organization. Sexually transmitted infections. Descriptive note 110 .

12. Díaz Machado A, Cruz Sánchez F, León Reyes S, Bess Constantén S, Podadera Valdés X (2017) Adolescence in Cuba. Indicators of their state of health. Rev Adoleca 19-34.

13. (2012) Sexuality Education Program with a Gender and Sexual Rights Approach in the national education system. Ministerial Resolution No.139, Ministry of Education, Havana.

14. Cortés Alfaro A, García Roché R, Duque Santana I, Ochoa Soto Aguilar Valdèz J (2006) Methodology for the prevention of STI-HIV / AIDS in adolescents and young people. National STI / HIV / AIDS Prevention Center. Editorial Lazo Inside. Havana.

15. Torres Cueto MA (2011) Sexuality education and prevention of STIs and HIV / AIDS from the gender, rights and sociocultural approaches. Secondary education, Pre-university, Professional and adult technique. Havana: Ministry of Education.

16. Hernández Sampieri R, Fernández Collado C, Baptita Lucio P (2014) Research methodology. 6th edition. Mexico: Editorial MCgraw-HillInteramericana.

17. Morales Ojeda R (2015) Universal health coverage. Cuban experience : cobertura-universal-de-salud-experiencia-cubana.

18. (2018) Ministry of Public Health, Statistical health yearbook Cuba.

19. (2017) Provincial Department of Health Department of medical records and health statistics. Mayabeque Statistical yearbook of health, Mayabeque.

20. Sarduy Lugo M, Sarduy Lugo A, Collado Cabañín L E (2015) Level of knowledge about HIV / AIDS in high school students. Rev Cubana Enfermer 31(4).

21. Communion Artieda A (2018) Sexually transmitted infections in adolescents, what the Primary Care pediatrician should know. Update in Pediatrics.

22. Castro Y, Falcón M, Valdés K, Díaz C, Martínez T (2015) Strategy of intervention on the perception of epidemiological factors of cervicouterine cancer. Cuban Journal of Obstetrics and Gynecology 41(3).

23. Chacón O’Farril D, Cortés Alfaro A, Álvarez García AG, Sotonavarro Gómez Y (2015) Pregnancy in adolescence, its family repercussion and in society. Rev Cubana Obstet Ginecol 41(1): 50-58.

24. Cortés Alfaro A, Chacón O’Farril D, Álvarez García AG, Sotonavarro Gómez Y (2015) Early maternity: impact on family health and society. Rev Cubana Medicina Integral 31(3): 376383.

25. García Odio AA, González Suárez M (2018) Risk factors associated with pregnant teenagers. Rev Medical Sciences 22(3).

26. Gómez G (2002) Human beliefs: a psychological perspective [Diploma Work]. Havana, Cuba: University of Havana.

27. Dutra Sehnem G, Rubim EN, Lúcia Beatriz Ressel, Maria Eduarda Deitos Vasquez (2018) Sexuality of adolescents that vivemcom HIV/aids: fontes de informação delimiting learned. Esc Anna Nery 22(1): e20170120.

28. Dessel AB, Kulick A, Wernik LJ, Sullivan D (2017) The importance of teacher suport: differential by gender and sexuality. Journal of adolescence 56: 136-144.

29. Ortíz Sánchez NL, Rodríguez González DA, Vázquez LM, Álvarez Aragón M, Sánchez Urra L (2015) Educational intervention on sexually transmitted infections in adolescents. Rev Med Electron 37(5): 418-429.

30. Villaseñor J, García P (2003) Psychosociology, Nature, Components: cognitive, affective and behavioral, Formation, Theories, Stereotypes, Prej- 
udices and Discrimination. Magazine of the Faculty of Psychology of the Autonomous University of Yucatan 12(5): 26-29.

31. Almeida Gacives WJ, Borges Acosta M, Bolufe Vilaza ME (2016) Educational activities for a responsible sexuality in adolescents from the uni-

ISSN: 2574-1241

DOI: 10.26717/BJSTR.2019.18.003214

Alba Cortes Alfaro. Biomed J Sci \& Tech Res

(C) This work is licensed under Creative

Submission Link: https://biomedres.us/submit-manuscript.php versity extension. Edumecentro 8(1): 174-180.

32. Cutié León E (2014) Sexually transmitted infections. In: Rigol Ricardo Orlando, Santiesteban Alba Stalina. Obstetrics and gynecology. Havana: ECIMED.

$\begin{array}{ll}\text { BIOMEDICAL } & \text { Assets of Publishing with us } \\ \text { RESEARCHES } & \text { - Global archiving of articles } \\ \text { - Immediate, unrestricted online access }\end{array}$

